\title{
Military Women: Changes in Representation and Experiences
}

\author{
Brenda L. Moore
}

\section{Contents}

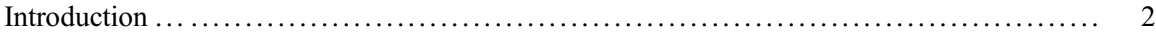

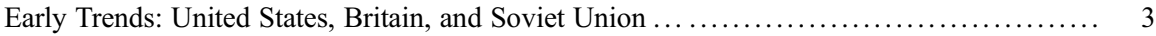

Post World War II and Beyond: Global Trends .................................. 5

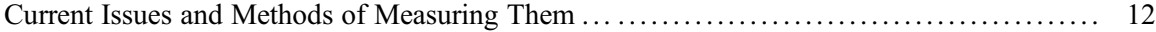

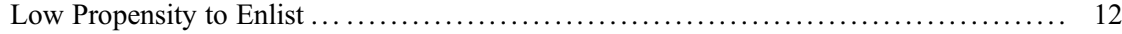

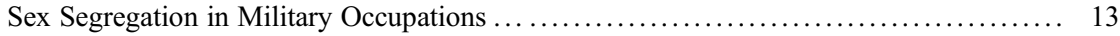

Sexual Harassment/Assault ................................................ 13

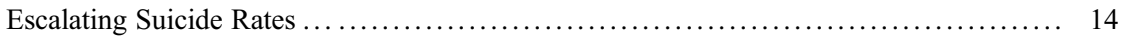

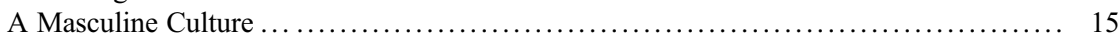

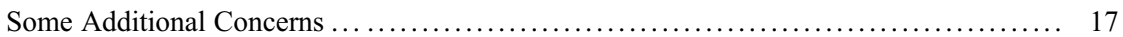

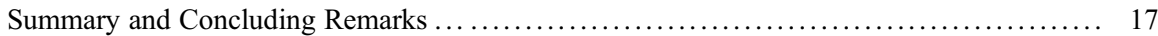

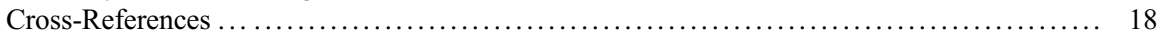

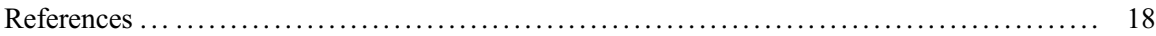

\section{Abstract}

Research on women in the military is becoming an increasingly important area of inquiry in the social sciences. Women are essential to the operation of contemporary armed services, and this has led to recent changes in organizational policies leaning toward equalizing the status of men and women in uniform. As the decades of the seventies and eighties witnessed an expansion in the role women would play in national defense, the twenty-first century is experiencing a movement toward parity between men and women in the military. This is the case not only in the United States, but in other nations as well. This movement toward gender equality is slow as it goes against the traditional social norms of most societies and is met with a number of obstacles. Although this chapter focuses primarily on historical and contemporary changes in the representation and

B. L. Moore ( $₫)$

Department of Sociology, University at Buffalo, SUNY, Buffalo, NY, USA

e-mail: socbrend@buffalo.edu 
experiences of women in the United States armed forces, there is also a brief examination of armed forces of other societies.

\section{Keywords}

Military $\cdot$ Servicewomen $\cdot$ Race and gender $\cdot$ Representation $\cdot$ Inclusivity $\cdot$ Sex segregation - Conscription · Propensity to enlist - War · Suicide rates - Sexual harassment/assault

\section{Introduction}

The character of gender relations in the armed services has always been reflective of that which exists in civilian society. In many ways, armed services reflect the cultures of societies in which they exist. This is largely due to the fact that the military, like other organizations, is dependent upon the larger society for resources. Thus it is only effective to the extent that it meets the demands of various interest groups concerned with its activities. On the other hand, the military is unique in terms of its primary goal, national defense. History has revealed that cultural norms are sometimes overlooked in times of national crises (consider the large number of women who served in the British and US militaries and those who fought in the Soviet Union during World War II). Today, we are witnessing a change in gender norms; women have developed a strong political voice that has moved societies more toward gender equality. The military institution's coercive compliance structure has compelled service members to adhere to newly implemented gender policies over the last four decades. In the United States, legislative changes have led to the opening of all military positions, including combat, to women. Arguably these policies would not have been enacted had they not been consistent with changes taken place in the civilian society. This chapter discusses changes in representation and experiences of women in the US armed services and, to a lesser degree, women in other countries.

Since the 1970s, percentages of active duty service women have been increasing. The United States has witnessed a number of legislative changes leading to increased opportunities for women to serve in the armed services. These changes are partly attributable to anti-discrimination regulations in civilian employment which has led to changes in employment both in the labor supply of women workers and the demand side of the market. Title VII of the Civil Rights Act of 1964 prohibits discrimination on the basis of sex in employment-related matters. As a result of Title VII, more women entered the workforce in the United States. These women worked mostly in clerical or service jobs, but more were entering skilled trades and managerial positions. Additionally, the advent of the All-Volunteer Force required services to compete with the civilian sector for qualified personnel (Moore 2017; Moskos 2000; US President Commission 1970). Advances in modern technology as well as the end of the Cold War also help to explain the expansion of women in the military (Moore 2017). 


\section{Early Trends: United States, Britain, and Soviet Union}

Women in the United States have been officially serving in the armed services since 1901; with the establishment of the Army Nurse Corps. During the nineteenth century, they served mostly as nurses, cooks, and laundresses. A few disguised themselves as men and served as soldiers in male units, only to be removed from service after their sexual identities were revealed. For example, a woman named Deborah Sampson dressed like a man and entered the Continental Army. Reportedly, a Lucy Brewer served as a marine on the USS Constitution during the War of 1812 (Holm 1982; Segal 1989). Harriet Tubman served as a spy and a scout for the Union Army during the Civil War (Clinton 2004). An African American woman and former slave named, Cathay Williams, posed as a man and served with the Buffalo Soldiers in the 38th Infantry, Company $A$ (Blanton 2007). A woman named Loreta Velasquez recruited and led Confederate soldiers in a number of battles during the Civil War (Segal 1989; Davis 2016). None of these women were officially members of the armed forces, and, regardless of how well they performed, they did not receive military honor because they were women.

Similarly, Mary Lacey, of Great Britain, disguised herself as a man and joined the Navy in 1759 and worked in the Naval Dockyard (Noakes 2006). Many women in Britain served unofficially as cooks, nurse maids, and a variety of services necessary to maintain fighting men. It is estimated that 20,000 women accompanied the British Army to the American colonies in 1776; many of whom were wives of soldiers (Noakes 2006:20). In 1860, the first Army Training School for military nurses was established by Florence Nightingale, and in 1866 female nurses were appointed to Military General Hospitals. It took another 18 years before the Army Nursing Service would come into existence in Britain (Noakes 2006).

During World War I, women again had limited opportunities to serve in the military, even though the armed services were suffering from an excessive manpower shortages. This was true in both Great Britain and the United States. In Great Britain, the National Union of Women's Suffrage Societies (NUWSS) organized the Women's Emergency Corps (WEC) in London. Through these organizations, British women were recruited to participate in the war effort by filling traditionally feminine positions as cooks, caregivers, and sometimes motor drivers (Harris 2003; Noakes 2006). The British Red Cross commissioned the First Aid Nursing Yeomanry to provide medical and ambulatory services for wounded British soldiers (Harris 2003; Noakes 2006). Unlike the United States, Britain created three auxiliaries in which women served as non-combatants during World War I. Approximately 90,000 British women served in the Women's Army Auxiliary Corps (WAAC), Women's Royal Navy Service (WRNS), and the Women's Auxiliary Air Force (WAAF) (Harris 2003; Noakes 2006:81). These auxiliaries would be demobilized after the World War I and would later be reactivated in 1939.

Comparable to Great Britain, the prevailing attitude on the part of the US War Department during World War I was that military jobs should be filled by men. The US Army admitted 20,000 women to serve only as nurses. The Navy and Marine Corps allowed a few women to enter as reservists to fill clerical occupations. 
Approximately 12,500 women served in the Navy as yeomen and another 1400 served in the Navy Nurse Corps (Segal 1989). Approximately 14 African American women served in the military during World War I as yeoman (Miller 1995; Miller 1919). The Marine Corps enrolled 300 women to work in clerical positions (Holm 1982). These women were demobilized after the war without military recognition (Treadwell 1954; Segal 1989).

World War II created a need for large numbers of women to participate in the military around the world. Thousands of women in the United States volunteered for military service. Women in Britain were drafted into the military. The Soviet Union assigned women as combatants. Although these women played an essential role to the war effort, they were not viewed as equal to their male counterparts in uniform. By most accounts, women who served during the World War II did not aspire to compete with men. They were satisfied to do the jobs they were assigned in an effort to release men to fight the war (Treadwell 1954; Moore 1996, 2003; Noakes 2006). Britain formed an additional auxiliary, the Auxiliary Territorial Services (ATS), which was attached to the Army. The WRNS was reactivated and attached to the Navy, and the WAAF was attached to the Royal Air Force. More than 400,000 women are reported to have served in the British armed services during World War II (Noakes 2006: 131).

Similarly, the greatest number of American women - some 400,000 - served in a variety of noncombatant assignments during the World War II. The US War Department consulted with a representative from the British Information Service to determine how best to establish a women's auxiliary corps in the US military (Treadwell 1954; Moore 1996: 38). The Women's Army Auxiliary Corps (WAAC) in the United States was established in March 1942. The following year, the WAAC was converted to the Women's Army Corps (WAC), giving women temporary, but full military status. Women were also recruited by the Navy to serve in the reserve corps as WAVES (Women Accepted for Volunteer Emergency Service). The Marine Corps' Women's Reserve was established, as well as the Coast Guard Women's Reserve.

Women were assigned mostly in clerical and administrative jobs to free men for combat. However, a small percentage of women served in such nontraditional roles as parachute riggers, aircraft mechanics, and intelligence (Moore 1996, 2003; Treadwell 1954). Some 6000 African American women served in racially segregated units in a variety of military occupations (including medical, clerical, motor pool) during the war (Putney 1992:viii; Moore 1996). More than 850 African American women were deployed to Europe as part of the 6888 Central Postal Directory Battalion to redistribute years of backlog mail. Some Japanese American women, many of whom were recruited from US internment camps, graduated the Military Intelligence Service Language School at Fort Snelling, Minnesota, and were later assigned to work in intelligence (Moore 2003). Other Japanese American servicewomen worked in a variety of military occupations to include the medical, supply, and clerical fields (Moore 2003). Sociologist, Brenda Moore (2003) gives a detailed account of the experiences of Japanese American women in the military during WWII. Her book is based on indepth interviews with some of the women who served and extensive archival analyses. American women of all racial and ethnic 
groups served in the United States and some in combat theaters overseas during World War II. These women were patriotic and for the most part did not question their role as noncombatants (Treadwell 1954; Moore 1996, 2003).

By contrast, over 800,000 women of the Eastern Front served in the military during World War II; many of whom were combatants serving in the trenches alongside men (Myles 1981; Saywell 1986: 131). Women in the Soviet Union served in many military specialties including members of the aircrews, tank crews, gun detachments, nurses, bomber pilots, and more. Three female air regiments ( 586 fighter aviation, 587 bomber aviation, and 588 night bomber units) were formed by a pilot named Marina Raskova for the Soviet Air Force (Saywell 1986). The 588th Night Bomber Regiment became part of the fourth Air Army and was given elite status (Guard Designation) for performance (Myles 1981).

\section{Post World War II and Beyond: Global Trends}

Following World War II, the number of women in uniform declined precipitously as they returned to their pre-war lives. Most of the women in the Soviet military left, and those who remained found the military environment unwelcoming to women, and their prior service deemed irrelevant (Saywell 1986; Segal 1993; Carreiras 2006). Great Britain was no longer drafting women, albeit the conscription was still in place, and the ATS relied on women to volunteer (Noakes 2006). In Britain, priority was given to rebuilding the home front, and many women were released to occupational positions considered to be feminine (Noakes 2006). A similar trend of leaving the military occurred in the United States as women returned to their civilian lives when the war had ended. Although some women opted to remain in uniform after the war, most left to resume their pre-war lives.

At the end of World War II, it became evident to the United States and Britain that the Soviet Union may pose a threat to Western democracy. All three nations worked on developing nuclear weapons and the Cold War had begun. Both Great Britain and the United States recognized the potential need for women in any future wars and enacted legislation to secure a permanent place for women in the armed services. On 20 November 1946, the British Parliament confirmed that women's auxiliary corps would be retained. The Auxiliary Territorial Services (ATS) and Women's Auxiliary Air Force (WAAF) would become members of the armed services and the Women's Royal Naval Service (WRNS) would remain as a civilian service (Noakes 2006). Two years later, in 1948, the United States gave permanent military status to women through the Women's Armed Services Integration Act of 1948 (PL-625). For the next two decades, the representation of women in the American armed services was restricted to 2\%. In 1967, Public Law 90-130 called for the removal of the 2\% restriction. Still, US women were disinclined to join the military and their representation in the military remained low.

There were more opportunities for women to serve in an All-Volunteer Force (AVF). Great Britain abolished conscription in 1960, more than a decade before the United States did. In both countries, women were encouraged to enter the AVF to 
help meet personnel goals. In the United States, the monetary and other work benefits of military service became an attractive career option to many racial minorities and women who found limited work options in civilian society. Women made up 3\% of the active duty forces in 1974. Five years later, the number of women in the US military had increased threefold; and the number of African American women had increased fivefold (Dorn 1989; Moore 1991, 1996).

Race has always been a salient issue in American society and was reflected in trends of representation and experiences of women in the US military throughout history. Overrepresentation of African American women among service women, particularly in the Army, raised interest among military scholars. Some scholars raised the concern that the overrepresentation of Blacks in the military would result in them bearing an unfair burden of defense. The scholars argued that the military should be reflective of the broader society (Dorn 1989). The services also began to exam the interaction effects of race and gender factors on the attitudes of military personnel. Some studies found that African American servicewomen were more pessimistic about the military's equal opportunity climate than white service women, (Moore and Webb 2000). In addition, African American female officers were more pessimistic than African American enlisted women (Dansby 2001; Rosenfeld, et al. 1992). Although African women were less satisfied with the equal opportunity climate than white women, they served longer terms and did not separate from service before their terms had expired as often as members of other racial/ethnic groups on active duty (Binkin et al. 1982, 52-53; Moore 1991, 2002). White women had a lower propensity of joining the military and were less likely than African American women to complete their term of service (Binkin et al. 1982, 52-53; Moore 1991; Moore and Webb 2000). Among the challenges faced by the services was to create initiatives to attract more white women and to more effectively meet the equal opportunity needs, such as inclusivity, of African American women (Moore and Webb 1998, 2000).

In the last four decades, changes in military laws and policies, largely influenced by a climate of equal employment opportunities for women in the broader society, have allowed for women to fill a wider array of military occupations. The trend has been movement toward gender inclusion in the military in the United States as well as other countries. In 1976, US Public-Law 94-106 opened the three major service academies to women. Two years later, Congress passed legislation abolishing the Women's Army Corps as a separate unit integrating women into the regular army.

Unlike previous years, women in the US military started the process of achieving higher ranks in the 1980s. Laws requiring women officers to be appointed, promoted, or separated from service differently from men were abolished in 1980 through the Defense Officer Manpower Personnel Management Act (DOPMA). As a result of DOPMA, US servicewomen could be promoted to grades 05 and above, and civilian husbands of female Nurse Corps officers were authorized dependent benefits (Moore 2017; Rostker et al. 1993). Since the 1990s, there is a greater variety of military occupations opened to US servicewomen. Congress lifted the ban on women flying combat aircraft and serving on combat ships in 1991. In the same year, more than 40,000 women soldiers were deployed to the Persian Gulf 
region during Operations Desert Shield and Storm; 15 were killed and two were taken prisoner of war (Lanning 2008:7). US women also participated in military operations in Somalia between 1992 and 1994, deployed for peacekeeping duties in Haiti in 1995, and participated in combat operations in Kosovo in 1999 (Lanning 2008).

Following the war, a US Government Accounting Office (GAO) report concluded that women performed well in combat and were an integral part of the operation (GAO 1993). Still, jobs specifically associated with submarines (Submarine Sonar Technicians, gun or missile crew-members) remained closed. Armor, Infantry, Special Forces, Cannon Field Artillery, and Multiple Launch Rocket Artillery occupations would not open to US servicewomen until 2010.

Although women in various countries throughout history have shown that they are capable to performing in combat, the notion of opening direct combat jobs to women in the United States even in the twenty-first century remained a contentious issue. Scholars, military officials, and news pundits all weighed in on the debate. Opponents emphasized biological differences between men and women, arguing that women are physically weaker than men, are at risk of becoming pregnant, and have an overall negative effect on the fighting capabilities of the American armed forces (see, e.g., Mitchell 1989, 1998). They raised the issue of military effectiveness, arguing that women lacked the strength and stamina to perform effectively in combat. It was also argued that the presence of women in combat units would undermine morale and cohesion (Mitchell 1989, 1998; van Creveld 2000; Kennedy-Pipe 2000). Other opponents maintained that whether or not women are capable of performing as warriors is not withstanding, it is more important for women to bear and raise children than to go off to war (Bruen 1991).

Advocates for lifting the ban on women serving in combat maintained that women should be granted the same opportunities as men to fulfill their citizenship duties (Segal 1982; Stiehm 1998, 1981). Another concern raised by advocates early on was that exclusionary policy hampers the career opportunities for women. Active duty military personnel are not likely to be promoted to the highest military ranks without combat experience (Becraft 1992; Burke 1996; Devilbiss 1985; Holm 1991). Advocates for women serving in combat assert that women's capabilities to perform effectively in war are equal to and sometimes surpass those of men (Segal 1982; Roush 1991; Holm 1991; Peach 1996). Others made the case that the combat exclusion law cannot protect military women from danger during wartime, but rather limits their chances for career advancement (Segal 1982; Becraft 1992).

US military women were divided over the issue of whether or not they should serve in combat. Findings from surveys of Army women from 1993 to 1994 revealed that enlisted women, and women of color, were more likely to oppose assigning women to combat (Miller 2001). Female officers were found to have greater advantages for serving in combat, than enlisted women, as they were more likely to plan a career in the military, less likely to have children, and more likely to perceive their command opportunities to be limited without combat experience (Miller 2001). Most of the Army women surveyed were in favor of women being 
able to volunteer for combat if and only if they were able to meet physical requirements (Miller 2001).

The example of the Israeli Defense Force (IDF) was often referenced during these debates as a country in which women were both drafted and served in combat since its inception in 1948. Although women in the IDF were assigned to combat units, they did not deploy for combat, but were evacuated when the unit went to war (Yuval-Davis 1981; Izraeli 1997). An exception was in 1948, during the Arab-Israeli War, when Israeli women took active part in land battles. Early studies showed that, as a rule, the majority of Israeli female soldiers served in secretarial and clerical jobs as did servicewomen in other countries (Gal 1986; Cohen 1997). Although Israeli women had been conscripted, there were many categories exempting them from service, to include marriage, having children, and religion. Women were also able to receive deferments to pursue a college education, so long as they completed military service upon graduation (Cohen 1997; Izraeli 1997). The Israeli Defense Force did not take all eligible 18-year-old women, but rather selected the number of women it needed to meet personnel quotas each year (Gal 1986; Yuval-Davis 1981; Klein 2002). Therefore, the entrance score requirements for women were higher than that for men (Gal 1986).

Israel continues to conscript men and women into the IDF; and men and women train together in today's Israeli military. Still, studies reveal that even today, the majority of women serving in the IDF are assigned to feminine roles; and that their service is not valued as highly as that of men (Karazi-Presler et al. 2018; RosmanStollman 2018). Although Israeli women comprise nearly $34 \%$ of the IDF, and $90 \%$ of the military occupations are open to women, only $4.6 \%$ of all women serve as combat soldiers (Karazi-Presler et al. 2018). Rosman-Stollman (2018) reports that Israeli servicewomen serve primarily in occupations in the Education Corps or in human resources. Unlike male-dominated military occupations, these positions, so Rosman-Stollman argues, do not generally yield tangible rewards in civilian society after servicewomen are discharged. Noteworthy is that Israeli female officers are overrepresented among junior officers; representing 56\% (Karazi-Presler et al. 2018). However, female officers in the IDF generally do not advance beyond the rank of major; representing only $14 \%$ of the officers in the rank of colonel and above (Karazi-Presler et al. 2018).

Contemporary changes in the structure of the IDF have given female junior officers opportunities to be promoted and serve in command positions in a variety of roles (Karazi-Presler et al. 2018). According to Karazi-Presler et al. (2018), junior officer women experience power and authority in their military positions. Their study is based on indepth retrospective interviews with 25 female officers in the Israeli military. Given the gendered structure of the military, these junior officers often express ambivalence about the power they have as officers. On the one hand, the women who had served as junior officers felt ashamed of wielding their power. On the other hand, many found the power they experienced in the military empowered and strengthened them in other aspects of their lives long after they had left the military (Karazi-Presler et al. 2018). There is also evidence that women serving in combat units in the IDF feel more empowered and have a greater sense of 
self-efficacy even when they had experienced life-threatening situations (Shahrabani and Garyn-tal 2019). Women who served in mixed-gender combat units stated that they had to work harder than the men in order to prove themselves, but through the process of proving themselves, they believed more in their own abilities (Shahrabani and Garyn-tal 2019).

During the first few years of the twenty-first century, US servicewomen continued to deploy to warzones (Yemen, Afghanistan, and Iraq) and served in combat, albeit unofficially. In 2004, Army women, known as Lioness, were assigned to Marine Corps ground combat units to assist on raids where women and children were present (Moore 2017). Later, the Female Engagement Team (FET) was developed and attached to military combat units to interact with local women in the rural regions of Afghanistan. By 2010, Fleet Ballistic Missile submarines (SSBN) and guided-missile attack submarines were open to US servicewomen (Moore 2017). Since 2013, all military occupations and units are officially open to women in the United States. US women have now completed combat leadership course in the US Army Ranger School (Moore 2017) and are officially attached to Special Forces in all-female Combat Support Teams (Moore 2017).

The trend of expanding military roles to include women is occurring in most Western countries, as well as Africa, Asia, and Australia (Moore 2017; Carreiras 2006). This trend has been facilitated by the United Nations Security Council Resolution 1325 which has established frameworks to include women in decision making processes about military operations. A study on women in North Atlantic Treaty Organization (NATO) forces reveals that all NATO countries recruit women on a volunteer basis and the percentages of military women in these countries are low, less than 15\% (Carreiras 2006). The NATO countries with the largest percentages of women in the year 2000 were the United States (14\%), Canada (11.4\%), France (8.5\%), the United Kingdom (8.1\%), and the Netherlands (8.0\%) (Carreiras 2006:99). The NATO countries with the lowest percentages of women included Italy $(0 \%)$, Poland $(0.1 \%)$, Turkey $(0.1 \%)$, Germany $(1.4 \%)$, and Norway $(3.2 \%)$. In this study, most women serve in the air force and fewest served in the army; and most serve in administrative support and medical positions (Carreiras 2006). A small fraction of women, 7\%, served in combat arms positions (Carreiras 2006).

Sweden's draft system constitutes an interesting case as both men and women 19 years of age are required to enlist in the military. This gender-neutral conscription system, which was implemented in 2018, has been decades in the making. Such a policy reflects Sweden's effort to insure that both women and men fulfill their obligation as citizens. Persson and Sundevall (2019) discuss the heated public debate that occurred over implementing a gender-neutral conscription in Sweden beginning with the youth league of the People's Party in 1965. A gender-neutral form of conscription was adopted as early as 2010 , but the conservative-liberal government of Sweden proposed a Bill (which was adopted by parliamentary majority) to deactivate it (Persson and Sundevall 2019). In 2017, due largely to perceived threats to national security, a coalition of Social Democrats and the Green Party reactivated conscription. Today, Swedish women serve in all military branches and positions including combat; but their percentages are low, and women are generally subjected 
to inadequate equipment. According Persson and Sundevall (2019), men comprise $85 \%$ of the selected conscripts and $93 \%$ of the professional military officers.

In the Ukrainian military, by contrast, a large number of occupations are closed to women. According to Martsenyuk and Grytsenko (2017), approximately $10 \%$ of the Ukrainian military are women; 14,500 female soldiers and 30,500 female contract employees of the armed services. Almost 2,000 Ukrainian women are officers, 35 of whom hold managerial positions in the Ministry of Defence. Of the 14,000 people in the National Guard, 21 are women holding positions of doctors and nurses (Martsenyuk and Grytsenko 2017). Many Ukrainian women serve informally. Unless a woman is formally classified as a combatant in the Ukrainian military, she will not receive military benefits when she departs service. Since 2016, Ukraine has implemented a National Action Plan to increase the number of women in the military and to introduce gender sensitivity training for military personnel in an effort to address gender-based violence. As of 2016, 63 staff positions, including some combat positions (i.e., bomb aimer, gunner, and scout, and sniper) are opened to women.

Australia also acknowledges the need to increase the representation of women in its defense force (ADF) particularly among the senior officers. Lee Hayward (2018) reports that women make up $12 \%$ of the Australian Army and are vastly underrepresented in the senior ranks. Although promotion to the senior ranks is based on a merit system, Hayward illustrates that the meritocracy reflects the values and biases of the decision-makers who are all male. Consequently the more senior the positions, the more homogenous they are. Hayward (2018) recommends that the Australian Army recognize the bias that is inherent the merit system and introduce new measures to achieve gender equality goals in the senior officer ranks.

The Jordanian armed forces (JAF) is relatively small, consisting of 100,000 active duty and 65,000 reservists (Maffey and Smith 2020). Women comprise only 4\% (or 3500) of all personnel in the JAF; most of whom serve in medical services (Maffey and Smith 2020). The role of women in the JAF is determined largely by gender norms within the family structure. Maffey and Smith (2020) discuss how these norms can range from traditional and restrictive to progressive and equitable. With the exception of war (i.e., the Lebanese war 1975-1991 and the Algerian War for Independence 1954-1962), women in the JAF are relegated to positions in education, health services, and business (Maffey and Smith 2020). Many women in the JAF expressed satisfaction with their military assignments and the opportunity to advance in rank vis-à-vis Jordanian women in the civilian labor force. However, the representation of women in the JAF lags behind other countries like Israel, the United States, and Norway. Maffey and Smith (2020) argue that the confluence of cultural, societal, political, and environmental factors impedes the career advancement of women in the JAF. The most prestigious positions are not offered to women as these occupations would require women to be away from their families for long periods of time (Maffey and Smith 2020). Jordan has recently developed an action plan for increasing the representation of women in the military.

According to an exploratory study of militaries in East Asia, China has a long history of ancient women warriors, including General Hao $\mathrm{Fu}$ who commanded 
more than 13,000 soldiers from 1250-1192 BC (Obradovic 2015). According to Lan Obradovic (2015), these ancient female warriors are still revered in China today. Women were first officially integrated in the People's Liberation Army (PLA) in 1967 and were recruited from the families of workers, peasants, soldiers, staff, and small merchants (Obradovic 2015). Between 1966 and 1976, during China's proletarian revolution, serving in the military was regarded as being a privilege for women. Lana Obradovic (2015) claims that Chinese women in uniform were glorified and were not discriminated against because of their gender. Today, China provides female military recruits with economic incentives (Obradovic 2015). Although there is not widely published information on women in the Chinese military today, Obradovic (2015) reports that they are assigned to various occupations to include signal, telegraph, submarines, space missions, and fighter jet pilots.

The Women's Army Corps in South Korea was officially established during the Korean War (Obradovic 2015). During that time, women served mainly in the medical field as surgeons, dentists, and nurses (Obradovic 2015). Since the 1990s, South Korean women have been fully integrated into all branches of military service; however their numbers remain relatively low compared to other democratic societies (Obradovic 2015). A reported 10,000 South Korean women serve among a total of 630,000 active duty personnel. The South Korean military is described as having a problem with discrimination against women, sexual harassment, and sexual violence. Violence against women in the South Korean military has been assessed as being a reflection of "means of reinforcing Confucian culture of gender hierarchy and hegemonic masculinity within the military institution (Obradovic 2015, p.10)."

Women comprise approximately $24 \%$ of the South African National Defense Force (SANDF). They receive the same training as men and have been serving in combat roles for two decades (Heinecken 2017). Still, as illustrated in a recent study, women are not fully accepted in the SANDF largely because of cultural norms, values, and practices (Heinecken 2017). Data for this study were collected during a Department of Defense (DoD) gender conference in Pretoria, South Africa in 2012. Most respondents (52\%) felt that combat service should be optional for women; while $39 \%$ felt that women should be compelled to serve as are men, and $10 \%$ believed that women should be barred from combat altogether. Still, the SANDF employs a gender-neutral policy in its effort to manage gender integration. Although norms are changing and the presence of women in the SANDF in various positions is beginning to be accepted, the service of women is not valued as highly as that of men. Lindy Heinecken argues that a gender-neutral perspective does not result in gender equality. This is because there are real gender differences and to expect women to perform the same as men is simply unfair.

The United States continues to make strides toward integrating women into the armed services. Recent data from the US Department of Defense reveals that in FY 2017 female representation in the active component (AC) reached its highest level in the history of the US military. US military women now comprise $16 \%$ of the enlisted forces and 18\% of the commissioned officers (DoD 2018b:6). In FY 2017, female representation among AC with no prior service (NPS) was highest in the Air Force (19.5\%), followed by the Navy (19.4\%), the Army (14.3\%), and the Marine Corps 
(8.5\%) (DoD 2018b:24). The percentage of racial minority servicewomen is almost doubled that of racial minority service men. As in previous years, overrepresentation of racial minority women (specifically African American women) in the enlisted force is related to their higher representation in AC NPS accessions as well as their higher retention rates (DoD 2018b). Racial minority women represented $41.4 \%$ of female Army accessions in FY2017, but racial minority men represented 26\% of male Army accessions (DoD 2018b:28). Hispanic women are over represented in the Marine Corps; however Hispanics are underrepresented in the enlisted active component (AC). The racial minority (or non-white category) is comprised mostly of African Americans. Similar to previous years, service women in FY2017 are most likely to work in administrative (25\%), medical (14.5\%), and supply (14.1\%) fields. The top three occupational categories for men, on the other hand, are electrical (21.9\%), infantry/bun crews/seaman (18\%), and supply (11.1\%) (DoD 2018b:26).

Women's representation among the active-component officer corps has been steadily increasing in all of the services with the exception of the Marine Corps since the onset of the AVF. The representation of female in the officer corps of the Marine Corps has been relatively low but has maintained a steady level. In FY2017, the Air Force had the highest representation of women in the active component officer corps (21\%), followed by the Navy and Army (17.8\%), and then the Marine Corps at 7.7\%. (DoD 2018b:32).

\section{Current Issues and Methods of Measuring Them}

\section{Low Propensity to Enlist}

There are a several issues which create obstacles to the full integration of women in the military globally. For the most part the problem of female integration is rooted in cultural norms. Scholarly studies have and continue to address these issues, which will require further investigation well into the future. Among many concerns is the low propensity of women to join the military. As mentioned above, the representation of women in the Swedish, Jordanian, Ukrainian, and South Korean military is low. The representation of women in the US armed services has increased but is also low. Women now comprise approximately $16 \%$ of the US active armed services. By contrast, women make up between $46 \%$ and $51 \%$ of the civilian labor force. This is controlling for women of comparable age and education makeup (college degree for officers) (DoD 2018b). Although 16\% is a noticeable increase in the representation of active duty women in recent years, it is much lower than the percentages of women in civilian society. Surely, women are grossly under represented in US armed service. The large representation of racial minorities in the enlisted ranks (particularly in the Army) most likely reflects the lack of adequate job opportunities for African Americans in the civilian labor market. This raises the issue of who bears the burden of national defense.

As mentioned above, gender disparity in military representation is not unique to the United States. Low representation of women in the services can be found in 
militaries globally (Segal 1993; Carreiras 2006; Martsenyuk and Grytsenko 2017; Persson and Sundevall 2019; Maffey and Smith 2020). Although women are underrepresented in the American armed services, the United States has the largest percentage of women in its military than other NATO countries (Carreiras 2006:99). This just further illustrates that low representation of women in the military is a global phenomenon.

\section{Sex Segregation in Military Occupations}

Another key issue is sex segregation in military occupations. Although all military positions in the United States are open to women, they are still concentrated in administrative, medical, and other support jobs (such as supply, electrical, electronics, and communications). This is in contrast to military men who are more likely to be in infantry, tactical operations, and equipment repair. Women are underrepresented in military career enhancing positions like infantry. This sex segregation in military occupations is also found in militaries in other countries (Carreiras 2006:105). Studies have shown sex segregation in military occupations to be a factor in women not advancing through the ranks as quickly as do men, which can ultimately obstruct their career progression (Segal 1982; Carreiras 2006). This issue is also of concern in militaries globally (Martsenyuk and Grytsenko 2017; Maffey and Smith 2020).

Contributing to the lack of representation of women in male-dominated service jobs is the lack of support they receive on the part of leadership. It is true the greater presence of women serving in the military challenges the notion that men are more capable than women. However military women are still expected to work in roles defined as appropriate for females. Recent studies of military academy students found that these budding military leaders are opposed to women serving in nontraditional roles (Laurence et al. 2016; Matthews et al. 2009). Examining survey data from service academy cadets, Reserve Officer Training Corps (ROTC) cadets, and college students, investigators found that service academy cadets who identified as male and Republican had the lowest approval scores, or the least support, for women serving in military roles (Laurence et al. 2017, 2016). Some scholars recommend aggressive training programs for future military leaders (Laurence et al. 2017, 2016).

\section{Sexual Harassment/Assault}

Over the last 30 years, sexual harassment/assault has been a primary issue in all of the services in the US armed forces and other countries as well. Although sexual harassment/assault is not unique to the military, it became associated with military organizations in the 1990s as a result of the Navy tailhook incident (1991), rape charges against male non-commissioned and commissioned officers at Maryland's Aberdeen Proving Ground (1997), and sexual harassment charges against the Sergeant Major of the Army (1998). Since then there have been a number of sexual harassment/assault charges concerning military personnel globally. In May 2013, the 
US Department of Defense developed a strategic plan (amended on January 2015) to unify the services in an effort to eliminate sexual assault. The current Sexual Assault Prevention and Response office (SAPRO) provides oversight, investigates claims, and publishes detailed annual reports on sexual assault involving members of the armed services. Each report presents statistical data and analyses and can be obtained through the following website: https://sapr.mil/reports.

Sexual misconduct in the military continues to be examined in scholarly literature as well. An example of a quantitative study recently published discusses the importance of organizational justice climate in alleviating sexual harassment in the workplace. Using data from two Department of Defenses' surveys, the 2006 Workplace and Gender Relations Survey (WGRS) and the Defense Equal Opportunity Climate Surveys (DEOCS), Rubino et al. examined the role of organizational justice climate as a predictor of sexual harassment and assessed its potential as a moderator of already established relationships between antecedents. Among the findings of this study is that organizations that effectively manage "justice climate," also deter sexual harassment. The investigators found that psychological and collective justice climate related negatively to sexual harassment and moderated the effects of sex similarity and sexual harassment climate on sexual harassment (Rubino et al. 2018).

Other inquiries about sexual harassment/assault are best examined through qualitative analyses. In today's society, sexual misconduct may take various forms other than direct contact with victims. A study of implications associated with containing the 2011 Australian Defense Force Academy (ADFA) Skype sex scandal is a good example. According to Habiba (2017), a female cadet of the ADFA went to the media and claimed that, unbeknownst to her, she had been Skyped via web cam having sexual intercourse with another cadet. The female cadet decided to go public with the event after learning that the accuser would only face a minor charge. As a result of the cadet going public, the ADFA Skype scandal resulted in the biggest scandal in Australian military history leading to investigations that unveiled hundreds of other cases of sexual abuse in the Australian Defense Force which had been concealed (Habiba 2017). Using qualitative methods, Boltandki's processes theory, and Bourdieu's field theory, Habiba analyzed how the handling of military sexual misconduct cases resulted in leakage of this information into the public domain. This led to heavy scrutiny of the protagonists as well as the processes within military organizations (Habiba 2017). By becomming public, the cost of the ADFA skype sex scandal increased for all stakeholders. The author concluded that to avoid negative consequences of scandals, organizations need to address conflicts (sexual or otherwise) in a timely fashion and explore all factors that contribute to it early on.

\section{Escalating Suicide Rates}

Another central concern is the accelerating suicide rate among military personnel in the United States which has surfaced over the last few years. Recently the RAND Corporation published data showing that the suicide rate among women in the military over the last 6 years has increased twice the pace of male service members. 
When compared to civilian women, military service women were two to five times more likely to take their own lives. The data were published in a RAND mulitmedia Veterans in American podcast on November 11, 2018. Military sexual trauma was found to be the main factor as well as combat stress disorder and other factors contributing to suicide among service women (see: Gorn 2018). DoD (2018b) reported that service members who died by suicide were younger than 30 years of age, usually enlisted and male. Other studies show that while men are more likely to die of suicide, women are more likely to attempt to take their lives (DoD 2019). Suicide rates are highest in the Army (24.3 suicides per 100,000 populations), followed by the Marine Corps (23.4), Navy (20.1), and lowest in the Air Force (19.3) (DoD 2019:v).

In 2018, the Department of Defense reported an increase in suicide rates among the active duty service members and higher than expected rates in the National Guard compared to the US population (DoD 2018a). Based on these results, the Department of Defense began implementing a multi-faceted public health approach to suicide prevention. Among DoD strategies for suicide prevention is an initiative to help enlisted Service members develop foundational skills to deal with life stressors early in their military career. DoD also supports military families by implementing strategies for them to increase awareness of risk factors for suicide (DoD 2018a). Each of the services (US Air Force, Army, Marine Corps, and Navy) are required to collect data and submit it to DoD for publication in its suicide event report. Every death by suicide and each identified suicide attempt must be reported. Much of the data are statistical and quantitative analyses are used in the reports which provide suicide rates, describing various factors associated with instances of suicide for each calendar year (DoD 2018a; DoD 2019).

Scholarly publications on suicide rates among military members focus on a variety of topics to include the impact of confidentiality on disclosure of suicidal thoughts (Anestis and Green 2015), combat exposure, and the risk of suicide thought (Bryan et al. 2015). Using a quantitative study, Reimann and Mazuchowski (2018) compare military suicide rates with civilian suicide rates, adjusting for age and sex differences from 2005 to 2014. According to their findings, suicide rates among US active duty service members increased between 2005 and 2009. They also found a significant association between higher suicide incidence for 17-29-year-old females in 2010, 2012, and 2014. Although these and other studies have been published on suicide rates among military personnel, so many more are needed to in an effort to better understand the causes and to best implement strategies of prevention.

\section{A Masculine Culture}

Arguably the main issue obstructing full integration of women in the armed services is the persistent culture of masculinity. This factor is articulated in studies of women in the military globally. Other issues like, low propensity to serve, sexual harassment/assault, and gender segregation in occupations may all be related to a culture that excludes women from full participation. Military men have voiced resentment 
toward the double standard between men and women in uniform. An early RAND study found that male soldiers were less concerned about gender differences and more concerned about structural inequality as it pertained to gender. For the service men who were surveyed, gender issues were not cited as affecting morale as often as were leadership issues. When male respondents raised gender as being an issue, they usually objected to a double standard in policies for men and women. "Men ... tended to assert that women demanded equal rights and recognition within the company but they were not equal in their performance or contribution to the unit... . Men claimed that female standards were too easy and that women were not being forced to meet even the lower standards (see: Harrell and Miller 1997:80)." Indeed, female service members were held to different physical fitness standards than men; required to do modified pull-ups, fewer push-ups; and allowed more time to meet running requirements. A Washington Times article published in 2002 revealed that men at military service academies resented that women were held to a lower standard (Washington Times 2002: 20).

There is a debate in social science literature on whether or not women should meet the same standards as men in order to qualify as good military personnel (Moore 2017). Some argue that in order for servicewomen to be successful, they must perform the same roles, and pass the same tests as male service members (King 2015). For King (2015), military women must be honorary men if they are to be respected in their military jobs. Others argue that women are not the same physiologically as men and do not aspire to be biologically equal to men (Brownson 2014, 2016). Brownson rejects King's assessment, arguing instead that service women aspire to a kinship-reciprocity ideal of equivalency, in which they are valued for the contributions they bring to the exchange (Brownson 2016).

Indeed, research confirms that men and women are physiologically different. One such study, using data from DoD's Armed Forces Health Surveillance Center, examined gender by race differences in self-reported post-traumatic stress disorder. Using a logistic regression analysis, the investigators found that more combat exposure were associated with a higher risk of PTSD (post-traumatic stress disorder) for service women compared to service men (Mustillo and Kysar-Moon 2017). Another research question raised by these investigator was whether or not Black female service members are at greater risk of experiencing PTSD following traumatic combat exposure than White female service members. They found no difference between black and white service women. The results of this study show that Black service women do not have a greater risk for PTSD than doWhite service women. However, service women are more vulnerable to traumatic stress exposure than are men (Mustillo and Kysar-Moon 2017). The issue of physiological differences between males and females merits continued discussion if women are to be fully integrated into the military. 


\section{Some Additional Concerns}

The topics mentioned above are only a few of the gender issues that will follow us well into the twenty-first century. Some issues pertaining to gender integration not discussed in this chapter, but nonetheless merit further investigation, include issues associated with pregnancy, obstetrics, and childcare. Strategic plans to strengthen family care plans for single parents making them more deployable warrants serious discussion (Booth et al. 2007). Ways to provide servicewomen with properly designed and fitted combat equipment also warrant careful exploration.

The goal of gender inclusivity is complicated, and there are a number of normative and practical issues yet to be resolved. Issues pertaining to women in the military are the focus of several committees in the nation's Capital. One such committee is the Defense Advisory Council on Women in the Services (DACOWITS), which reports to the Secretary of Defense on matters relating to women in the US military. The Committee consists of qualified professional women in the US armed forces. They make recommendations on policies relating to recruitment and retention, employment, integration, well-being, and treatment. Each year DACOWITS publishes minutes of their meetings as well as a report of its research findings and recommendations. These data can be obtained through the following website: https:// dacowits.defense.gov/Reports-Meetings/.

Among the issues addressed in their FY 2018 report are (i) variance in women's recruitment and retention by race/ethnicity, conscious and unconscious gender bias in the services, underrepresentation of female chaplains, revised physical fitness tests accounting for physiological gender differences, gender integration of women in ships, pregnancy and parenthood policies, and domestic violence affecting servicewomen (see: DACOWITS 2018).

\section{Summary and Concluding Remarks}

The issue of whether or not women should serve in combat is less about a woman's ability to do so and more about cultural norms and gender roles. For sure, women have filled the role of combatants throughout history. During times of conflict, nations have drafted and recruited the services of women. During times of peace, the service of women has fallen into obscurity. A number of structural changes that have occurred over the last four decades in an effort to remove institutional barriers to the integration of women in the military globally have been reviewed. In the United States, opportunities for women to be assigned to occupations that had been previously closed to them were ushered in with the All-Volunteer Force. Doors to aviation duty in noncombat aircraft, as well as noncombatant ships, opened to women. Service academies began to enroll women. The 1980s witnessed even more changes in Congressional laws and military policies moving closer to integrating women in the services. Not only are there more occupational positions available to US military women, but more family support services such as medical, and childcare are provided for service members. Quality of life concerns, such as living 
facilities, have been addressed by each of the services in an effort to attract good women as well as good men. Although physical constraints which have categorically excluded women from the armed services have been removed, women are still vastly underrepresented.

A question is why should societal members concern themselves with the representation of women in the military? What is really at issue? To answer that question, one must consider the fact that throughout history, militaries of Western democracies (and elsewhere) have been male dominated institutions based on a culture of masculinity (Enloe 1981). Traditionally, service in the military was both a right and an obligation of citizens (Marshall 1950; Janowitz 1975); and full citizenship with all of the accompanying rights was reserved exclusively for men. If women are to be first class citizens, then it follows that they must actively participate in the national defense and peacekeeping efforts.

\section{Cross-References}

Dynamic Intersection on Military and Society

\section{References}

Anestis, M. D., \& Green, B. A. (2015). The impact of varying levels of confidentiality on disclosure of suicidal thoughts in a sample of United States National Guard Personnel. Journal of Clinical Psychology, 71(10), 1023-1030.

Becraft, C. H. (1992). Women and the military: Bureaucratic policies and politics. In E. A. Blacksmith (Ed.), The reference shelf: Women in the military (pp. 8-17). New York: H. W. Wilson.

Binkin, M., Eitelberg, M., Schexnider, A., \& Smith, M. (1982). Blacks and the military. Washington, D.C.: Brookings Inst.

Blanton, D. (2007). In B. Glasrud \& M. Searles (Eds.), Buffalo soldiers in the west: A black soldiers anthology. College Station: Texas A\&M University Press.

Booth, B., Segal, M. W., Bell, B., Martin, J., Ender, M., Rohall, D., \& Nelson, J. (2007). What we know about Army families: 2007 update. Caliber: U.S. Army MWR.

Brownson, C. (2014). The battle for equivalency: Female US marines discuss sexuality, physical fitness, and military leadership. Armed Forces and Society, 40, 765-788.

Brownson, C. (2016). Rejecting patriarchy for equivalence in the US military: A response to Anthony King's "women warriors: Female accession to ground combat". Armed Forces and Society, 42, 235-242.

Bruen, J. G. (1991). Combat is not an appropriate role for women. In C. Wekesser \& M. Polesetsky (Eds.), Women in the military: Current controversies (pp. 82-85). San Diego: Greehhaven Press.

Bryan, C. J., Griffith, J. E., Pace, B. T., Hinkson, K., Bryan, A. O., Clemans, T. A., \& Imel, Z. E. (2015). Combat exposure and risk for suicidal thoughts and behaviors among military personnel and veterans: A systematic review of meta-analysis. Suicide Life Threatening Behavior, 45, 633-649.

Burke, C. (1996). Pernicious cohesion. In Stiehm, J. H. (Ed.) It's our military too!: Women and the U.S. Military. Philadelphia: Temple University press, pp. 205-219.

Carreiras, H. (2006). Gender and the military: Women in the armed forces of Western democracies. New York: Routledge Press. 
Clinton, C. (2004). Harriett Tubman: The road to freedom. New York: Little Brown \& Company. Cohen, S. A. (1997). Toward a new portrait of the new Israeli soldier. Israel Affairs, 3(3/4), 77-114.

DACOWITS (U.S. Defense Advisory Committee on Women in the Services). (2018). Annual report. Washington, DC: Pentagon. https://dacowits.defense.gov/Portals/48/Documents/Reports/2018/ Annual\%20Report/DACOWITS\%20Annual\%20Report\%202018.pdf?ver=2019-03-11-115325640. [Accessed 1/8/20].

Dansby, M. R. (2001). Cultural diversity and gender issues. In M. R. Dansby, J. B. Stewart, \& S. C. Webb (Eds.), Managing diversity in the military: Research perspectives from the defense equal opportunity institute. New Brunswick: Transaction Publishers.

Davis, W. C. (2016). Inventing Loreta Velasquez: Confederate soldier impersonator, media celebrity, and con artist. Carbondale: Southern Illinois University Press.

Devilbiss, M. C. (1985). Gender integration and unit deployment: A study of GI jo. Armed Forces and Society, 11(4), 523-552.

DoD (2018a). Annual suicide report calendar year 2018. Washington, D.C.: Office of the Under Secretary of Defense, Personnel and Readiness. Published 2019. Accessed January 7, 2020. https:// assets.documentcloud.org/documents/6432219/2018-DoD-Annual-Suicide-Report-FINAL-25-SEP19.pdf

DoD (2018b). Population representation in the military services: Fiscal year 2017 summary report. Washington, DC: Office of the Under Secretary of Defense, Personnel and Readiness. Published 2018. Accessed June 12, 2019. https://www.cna.org/poprep/2017/download/download.html

DoD (2019). DODSER Department of Defense Suicide Event Report. Washington, D.C.: Office of the Under Secretary of Defense, Personnel and Readiness. Accessed 7 Jan 2020. https://www. pdhealth.mil/sites/default/files/images/docs/TAB_B_DoDSER_CY_2017_Annual_Report_ 508_071619.pdf

Dorn, E. (1989). Who defends america? Race, sex, and class in the armed forces. Washington, DC, Joint Center for Political Studies.

Enloe, C. (1981). The military model. In W. Chapkis (Ed.), Loaded questions: Women in the military (pp. 23-29). Amsterdam: Transnational Institute.

Gal, R. (1986). A portrait of the Israeli soldier. Westport: Greenwood Press.

GAO. (1993). Women in the military: Deployment in the Persian Gulf war. Washington, DC: General Accounting Office.

Gorn, D. (2018). Why So Many Military Women Think About Suicide. https://www.rand.org/multime $\mathrm{dia} /$ podcasts/veterans-in-america/why-so-many-military-women-think-about-suicide.html

Habiba, P. (2017). The Australian defense force academy skype sex scandal: Understanding the implications of containment. In Armed Forces and Society, 43(2), 300-321.

Harris, C. (2003). Women at war 1939-1945: In uniform. Stroud: Sutton Publishing Ltd..

Hayward, L. (2018). Increasing the number of senior women in the Australian Army. Security Challenges, 14(2), 37-48.

Heinecken, L. (2017). Conceptualizing the tensions evoked by gender integration in the military: The South African case. In Armed Forces and Society, 43(2), 202-220.

Holm, J. (1982). Women in the military. Novato: Presidio Press.

Holm, J. (1991). The Persian Gulf proved that women can serve in combat. In C. Wekesser \& M. Polesetsky (Eds.), Women in the military: Current controversies (pp. 67-72). San Diego: Greehhaven Press.

Izraeli, D. N. (1997). Gendering military Service in the Israeli Defense Force. Israel Social Science Research, 12(1), 129-166.

Janowitz, M. (1975). The all-volunteer military as a sociopolitical problem. Social Problems, 22, 432-449.

Karazi-Presler, T., Sasson-Levy, O., \& Lomsky-Feder, E. (2018). Gender, emotions management, and power in organizations: The case of Israeli women junior military officers. Sex Roles, 78, 573-586.

Kennedy-Pipe, C. (2000). Women and the military. The Journal of Strategic Studies, 23(December), 32-50. 
King, A. (2015). Women warriors: Female accession to ground combat. Armed Forces \& Society, 41, 379-387.

Klein, U. (2002). The gender perspective of civil-military relations in Israeli society. Current Sociology, 50(5), 669-686.

Lanning, L. (2008). Women in the military: Where they stand (6th ed.). Arlington: Research and Education Institute (WREI).

Laurence, J. H. (2017). Women and the U.S. military: Progress and challenges. In D. E. Rohall, M. G. Ender, \& M. D. Matthews (Eds.), Inclusion in the American military: A force for diversity (pp. 111-127). New York: Lexington Books.

Laurence, J.H., Milavec, B.L., Rohall, D.E., Ender, M.G., \& Mathews, M.D., (2016). Predictors of support for women in military roles: Military status, gender, and political ideology. Military Psychology, 2/(2), 241-251.

Maffey, K. R., \& Smith, D. G. (2020). Women's participation in the Jordanian military and police: An exploration of perceptions and aspirations. Armed Forces \& Society, 46(I), 46-67.

Marshall, T. H. (1950). Citizenship and social class. Cambridge: Cambridge University Press.

Martsenyuk, T., \& Grytsenko, G. (2017). Women and military in Ukraine: Voices of the invisible battalion. Ukraine Analytica, 1(7), 29-37.

Matthews, M. D., Ender, M. G., Laurence, J.H., \& Rohall, D.E. (2009). Role of group affiliation and sex on attitudes toward women in the military. Military Psychology, 2/(2), 241-251.

Miller, K. (1919). The history of the world war for human rights. Washington, DC: Jenkins and Keller.

Miller, R. E. (1995). The Golden fourteen, plus: Black navy women in World War One. MINERVA: Quarterly Report on Women and the Military, XIII(3 \& 4, Fall/Winter), 7-13.

Miller, L. L. (2001). Feminism and the exclusion of army women from combat. In R. Simon (Ed.), Women in the military (pp. 103-133). New Brunswick: Transaction Publishers.

Mitchell, B. (1989). Weak link: The feminization of the American military. Washington, D.C.: Regnery Publishing.

Mitchell, B. (1998). Women in the military: Flirting with disaster. Washington, D.C.: Regnery Publishing.

Moore, B. L. (1991). African American women in the U.S. Military. Armed Forces and Society 17, no. 3 (Spring): 363-365.

Moore, B. L. (1996). To serve my country, to serve my race: The story of the only African American WACs stationed overseas during World War II. New York: New York University Press.

Moore, B. L. (2003). Serving our country: Japanese American women in the military during World War II (p. 2003). New Jersey: Rutgers University Press.

Moore, B. L. (2017). Introduction to special issue on women in the military. Armed Forces and Society, 43(2), 191-201.

Moore, B. L., \& Webb, S. (1998). Equal opportunity in the U.S. Navy: Perceptions of AfricanAmerican women. Gender Issues, 16(3), 99-119.

Moore, B. L., \& Webb, S. (2000). Perceptions of equal opportunity among women and minority Army personnel. Sociological Inquiry, 70(2), 215-239.

Moskos, C. C. (2000). Toward a postmodern military: The United States as a paradigm. In C. C. Moskos, J. A. Williams, \& D. R. Segal (Eds.), The postmodern military: Armed forces after the Cold War (pp. 14-31). New York/Oxford: Oxford University Press.

Mustillo, S., \& Kysar-Moon, A. (2017). Race, gender, and post-traumatic stress disorder in the U.S. military: Differential vulnerability? In Armed Forces and Society, 43(2), 322-345.

Myles, B. (1981). Night witches: The untold story of soviet women in combat. Novato: Presidio Press.

Noakes, L. (2006). Women in the British Army: War and the gentle sex, 1907-1948. New York: Routledge.

Obradovic, L. (2015). Comparative analysis of Women's military participation in East Asia. Res Militaris (http://resmilitaris.net), ERGOMAS issue no 1, Women in the military, Part One, September. 
Peach, L. J. (1996). Gender ideology in the ethics of women in combat. In J. H. Stiehm (Ed.), It's our military too: Women and the U.S. Military. Philadelphia: Temple University Press.

Persson, A., \& Sundevall, F. (2019). Conscripting women: Gender, soldiering, and military service in Sweden 1965-2018. Women's History Review, 28(7), 1039-1056.

Putney, M. S. (1992). When the nation was in need: Blacks in the Women's Army Corps during World War II. New Jersey: Scarecrow Press.

Reimann, C. A., \& Mazuchowski, E. L. (2018). Suicide rates among active duty service members compared with civilian counterparts, 2005-2014, Military Medicine, 183(suppl_1), 396402.

Rosenfeld, P., Culbertson, A., Booth-Kewley, S., \& Magnusson, P. (1992). Assessment of equal opportunity climate: Results of the 1989 navy-wide survey. San Diego: Navy Personnel Research and Development Center.

Rosman-Stollman, E. (2018). Military service as bargaining: The case of religious women soldiers in Israel. Politics, Religion \& Ideology, 19(2), 158-175.

Rostker, B., Thie, H., Lacy, J., Kawata, J., \& Purnell, S. (1993). The defense officer personnel management act of 1980: A retrospective assessment. Santa Monica: RAND. Retrieved from http://www.rand.org/content/dam/rand/pubs/reports/1993/R4246.pdf.

Roush, P. E. (1991). Women serving in combat would strengthen America's defense. In C. Wekesser \& M. Polesetsky (Eds.), Women in the military: Current controversies (pp. 59-63). San Diego: Greehhaven Press.

Rubino, C., Avery, D. R., McKay, P. F., Moore, B. L., Wilson, D. C., Van Driel, M. S., Witt, L. A., \& McDonald, D. P. (2018). And justice for all: How organizational justice climate deters sexual harassment. Personnel Psychology, 71(4), 519-544.

Saywell, S. (1986). Women in war: From World War II to El Salvador. Ontario: Penguin Books.

Segal, M. W. (1982). The argument for female combatants. In N. L. Goldman (Ed.), Female soldiers: Ombatant or noncombatant? (pp. 267-290). Westport: Greenwood Press.

Segal, D. R. (1989). Recruiting for uncle Sam: Citizenship and military manpower policy. Lawrence: University Press of Kansas.

Segal, M. W. (1993). Women in the armed forces. In R. H. Howes \& M. R. Stevenson (Eds.), Women and the use of force (pp. 81-93). Boulder/London: Lynne Rienner Publ.

Shahrabani, S., \& Garyn-tal, S. (2019). The impact of prior combat military service on Israeli women's self-efficacy and risk attitudes. Women's Studies International Forum, 74, 143-153.

Stiehm, J. H. (1981). Bring me men and women. Berkeley: University of California Press.

Stiehm, J. H. (1998). Army opinions about women in the Army. Gender Issues, 3(16), 88-98.

Treadwell, M. E. (1954). The Women's Army corps. United States Army in World War II: Special studies. Washington, DC: U.S. Government Printing Office.

U.S. President's Commission. (1970). The report of the President's commission on an all-volunteer force. Washington, DC: Government Printing Office.

Van Creveld, M. (2000). Less than we can be, women and the modern military. The Journal of Strategic Studies, 23(December), 21-31.

Washington Times. (2002). No women in combat. Editorial, 8, 20.

Yuval-Davis, N. (1981). The Israeli example. In W. Chapkis (Ed.), Loaded questions: Women in the military (pp. 73-77). Transnational Institute: Amsterdam.

\section{Further Readings}

Alchin, A., Gouws, A., \& Heinecken, L. (2018). Making a difference in peacekeeping operations: Voices of south African women peacekeepers. African Security Review, 27(1), 1-19.

Bouka, Y., \& Sigsworth, R. (2016). Women in the military in Africa: Kenya case study. Institute for Security Studies.

Gustavsen, E. (2013). Equal treatment or equal opportunity? Male attitudes toward women in the Norwegian and US armed forces. Acta Sociologica, 56(4), 361-374.

Hong, D.-S. (2002). Women in south Korean military. Current Sociology, 50(5), 729-743. 
Kim, K.-J. (2011). Women and homosexuals in the south Korean defense force: Possibility and limitation of their full integration. The Korean Journal of International Studies, 9(2), 233-260.

Levin, D. S. (2011). You're always first a girl: Emerging adult women, gender, and sexuality in the Israeli army. Journal of Adolescent Research, 26(1), 3-29.

Rosamond, A. B., \& Kronsell, A. (2018). Cosmopolitan militaries and dialogic peacekeeping: Danish and Swedish women soldiers in Afghanistan. International Feminist Journal of Politics, 20(2), 172-187.

Sand, T. S., \& Fasting, K. (2016). Non-Commissioned Officers and Attitudes toward Military Women in the Norwegian Air Force: It's always nice when there are girls around. Res Militaris (http://resmilitaris.net), EROGOMAS issue n1, Women in the Military, Part Two.

Sasson-Levy, O. (2003). Feminism and military gender practices: Israeli women soldiers in masculine roles. Sociological Inquiry, 73(3), 440-465.

Teaiwa, T. (2015). What makes Fiji women soldiers? Context, context, context. Intersections: Gender and Sexuality in Asia and the Pacific, 37.

Zimmermann, P., Strohle, A., Langner, F., \& Lancik, M. (2010). Utilization of psychiatric services by female military personnel changes since admission of women to all German armed forces military careers. Military Medicine, 175(7), 494.

Open Access This chapter is licensed under the terms of the Creative Commons Attribution 4.0 International License (http://creativecommons.org/licenses/by/4.0/), which permits use, sharing, adaptation, distribution and reproduction in any medium or format, as long as you give appropriate credit to the original author(s) and the source, provide a link to the Creative Commons license and indicate if changes were made.

The images or other third party material in this chapter are included in the chapter's Creative Commons license, unless indicated otherwise in a credit line to the material. If material is not included in the chapter's Creative Commons license and your intended use is not permitted by statutory regulation or exceeds the permitted use, you will need to obtain permission directly from the copyright holder.

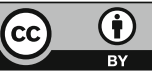

